(C) 2017

Коне М. С., кандидат ветеринарних наук

Полтавська державна аграрна академія

Забіяка О. О., лікар ветеринарної медицини

ТОВ «Біоцентр», м. Полтава

\title{
ЕФЕКТИВНІСТЬ ЛІКУВАННЯ ТА ПРОФІЛАКТИКИ ІНФЕКЦИЙНОГО РИНОТРАХЕЇТУ КОТІВ В УМОВАХ ВЕТЕРИНАРНИХ КЛІНІК ТОВ «БІОЦЕНТР» (ПОЛТАВА)
}

\section{Рецензент - кандидат ветеринарних наук О. В. Кручиненко}

Вивчено вікову та породну чутливість, сезонність виникнення та динаміку прояву інфекційного рино трахеїту у котів в умовах ветеринарних клінік ТОВ «Біочентр» міста Полтава. Запропоновано різні схеми лікування інфекиійного ринотрахеїту котів. Встановлено, що інфекційний ринотрахеїт частіше реєструється серед котів віком від двох місяиів до одного року. Більш схильні до захворювання безпородні тварини. Хвороба має виражену сезонність, щзо проявлясться частішими випадками виникнення інфекиійного ринотрахеїту у весняно-літньо-осінній періоди. Запропонована нами схема лікування інфекиійного ринотрахеїту котів забезпечує високу терапевтичну ефективність.

Ключові слова: інфекційний ринотрахеїт, кіт, лікування, схема, ефективність.

Постановка проблеми. Інфекційний ринотрахеїт (англ. Feline viral rhinotracheitis - FVR) високо контагіозна вірусна гостропротікаюча хвороба, яка характеризується різким підвищенням температури, ринітом, кон'юнктивітом, катаральним запаленням верхніх дихальних шляхів $[1,3]$.

Інфекційний ринотрахеїт на сьогодні лишається одним із найпоширеніших вірусних інфекційних захворювань котів, що призводить до значних економічних і моральних втрат. Загальні економічні збитки від даної хвороби складаються із затрат, пов'язаних із загибеллю тварин та на проведення профілактичних, протиепізоотичних і лікувальних заходів [2, 4-6].

Аналіз останніх досліджень і публікацій, у яких започатковано розв'язання проблеми. Аналізуючи дані журналів реєстрації хворих тварин ветеринарних клінік ТОВ «Біоцентр» за 2013-2015 роки, можна зробити висновок, що місто Полтава $є$ неблагополучним стосовно інфекційного ринотрахеїту котів. Провідні лікарі ветеринарних клінік міста стверджують, що за останні роки почастішали випадки захворюваності котів інфекційними хворобами, зокрема й інфекційним ринотрахеїтом. У зв'язку з цим виникає потреба в розробці нових ефективних схем лікування та профілактики даної хвороби.

Діагностика захворювання складна й проводиться комплексно на підставі епізоотологічних даних, клінічних ознак та результатів лабораторних досліджень [7,8].

Метою наших досліджень $\epsilon$ аналіз епізоотичного процесу інфекційного ринотрахеїту котів в умовах ветеринарних клінік ТОВ «Біоцентр» міста Полтава.

Завдання - провести порівняльну оцінку схем лікування інфекційного ринотрахеїту у котів i розробити найбільш ефективну схему терапії та профілактики у тварин.

Матеріали і методи досліджень. Дослідження проводилися в період 2013-2015 років на базі ветеринарних клінік ТОВ «Біоцентр» міста Полтава.

Для вивчення порівняльної ефективності різних схем лікування інфекційного ринотрахеїту у котів в умовах зазначених ветеринарних клінік ТОВ «Біоцентр» нами було відібрано три різні вікові групи тварин (по 7 котів у кожній), хворих на гостру форму. Тварин відбирали за принципом аналогів.

На базі приватного заводчика британської короткошерстої породи кішок О.О. Зуєвої, яка проживає в зоні діяльності ветеринарних клінік ТОВ «Біоцентр» міста Полтава, 3 метою порівняльної оцінки ефективності різних вакцин проти інфекційного ринотрахеїту нами був поставлений дослід. За період із липня по грудень 2015 року в розпліднику окотилися 5 кішок. У цілому від них було одержано 30 кошенят британської породи. 3 народжених кошенят було сформовано 3 дослідні групи (по 10 тварин у кожній).

Для профілактики інфекційного ринотрахеїту котів використовували наступні вакцини: «Біофел», «Пуревакс», «Нобівак трикет».

Результати дослідження. Для оцінки епізоотичної ситуації щодо інфекційного ринотрахеїту 


\section{ВЕТЕРИНАРНА МЕДИЦИНА}

в місті Полтава ми аналізували дані ветеринарної звітності по захворюваності котів у ветеринарних клініках ТОВ «Біоцентр».

Результати аналізу породної сприйнятливості котів до інфекційного ринотрахеїту свідчать про те, що частіше ця хвороба у місті Полтава реєструється серед безпородних тварин.

Найчастіше інфекційний ринотрахеїт реєстрували у кішок у віці від двох місяців до одного року.

Крім того слід звернути увагу на те, що кошенята до двох місяців не хворіють, що $з$ нашого погляду, є наслідком вищого імунного захисту кошенят, які одержують антитіла 3 молозивом матері.

Аналізуючи отримані дані, ми встановили, що для інфекційного ринотрахеїту котів характерна сезонність перебігу: частіше дане захворювання реєструється у зимово-весняно-осінній період.

3 метою визначення ефективності різних схем терапії гострої форми інфекційного ринотрахеїту котів трьох сформованих груп лікували різними комплексами препаратів. Результати дослідження різних схем лікування котів у клініках ТОВ «Біоцентр» наведені в таблиці 1.

Як свідчать дані таблиці 1, найбільшу ефективність лікувальних заходів отримали за використання схеми, що включала $5 \%$ розчин «Енрофлоксу», «Фоспреніл», «Ронколейкін», «Гамавіт»,
«Катозал», РБС. Терапевтична ефективність становить $100 \%$.

Результати проведеного досліду 3 вивчення ефективності вакцинації проти інфекційного ринотрахеїту у кішок відображені у таблиці 2 .

Аналізуючи отримані дані таблиці 2, ми встановили, що найефективнішим виявився третій метод профілактичної вакцинації («Пуревакс»). Із 10-ти тварин жодна не захворіла.

\section{Висновки:}

1. Інфекційним ринотрахеїтом хворіють кішки різних порід, проте частіше дане захворювання реєструється серед безпородних тварин.

2. Ензоотія інфекційного ринотрахеїту у кішок має виражену сезонність (частіше проявляється у зимово-весняно-осінній період).

3. Інфекційний ринотрахеїт реєструється у кішок різного віку, але більш схильні до зараження тварини віком від двох місяців до одного року.

4. Розроблена нами схема лікування, що включає $5 \%$ розчин «Енрофлокса», «Фоспреніл», «Ронколейкін», «Гамавіт», «Катозал» і РБС у дозах відповідно до ваги тварини має найвищу ефективність (100\%).

5. Для профілактики інфекційного ринотрахеїту котів найбільш ефективною виявилася вакцина «Пуревакс».

\section{1. Терапевтична ефективність різних схем лікування інфекційного ринотрахеїту котів (n=7)}

\begin{tabular}{|c|c|c|c|c|c|}
\hline \multirow{2}{*}{$\begin{array}{c}\text { Група } \\
\text { тварин }\end{array}$} & Схема лікування & \multicolumn{2}{|c|}{ Одужало } & \multicolumn{2}{|c|}{ Загинуло } \\
\cline { 3 - 5 } 1 & $\begin{array}{c}5 \% \text { розчин «Енрофлоксу»+ } \\
\text { «Гамавіт»+ «Катозал»+ РБС } \\
\text { «Ронколейкін»+ «Фоспреніл» }\end{array}$ & 7 & 100,0 & - \\
\hline \multirow{2}{*}{2} & $\begin{array}{c}5 \% \text { розчин «Енрофлоксу»+ } \\
\text { «Гамавіт»+ «Катозал»+ РБС }+ \\
\text { «Фоспреніл» }\end{array}$ & 5 & 71,43 & 2 & 28,57 \\
\hline 3 & $\begin{array}{c}5 \% \text { розчин «Енрофлоксу»+ } \\
\text { «Гамавіт»+ «Катозал»+ РБС }\end{array}$ & 4 & 57,14 & 3 & 42,86 \\
\hline
\end{tabular}

Примітка: $\mathrm{n}$ - кількість тварин у групі

\section{2. Порівняльна ефективність різних вакцин за профілактичної імунізації кішок $(n=10)$}

\begin{tabular}{|c|c|c|c|c|c|}
\hline \multirow{2}{*}{$\begin{array}{c}\text { Група } \\
\text { тварин }\end{array}$} & Вакцини & \multicolumn{2}{|c|}{ Не захворіло } & \multicolumn{2}{|c|}{ Захворіло } \\
\cline { 3 - 6 } & $\begin{array}{c}\text { абсолютне } \\
\text { число }\end{array}$ & $\begin{array}{c}\text { абсолютне } \\
\text { число }\end{array}$ & 2 & 20,0 \\
\hline 1 & «Біофел» & 8 & 80,0 & 1 & 10,0 \\
\hline 2 & «Нобівак трикет» & 9 & 90,0 & - & - \\
\hline 3 & «Пуревакс» & 10 & 100,0 & - & 2 \\
\hline
\end{tabular}

Примітка: $\mathrm{n}$ - кількість тварин у групі 


\section{БІБЛІОГРАФІЯ}

1. Борисевич В. Б. Болезни кошек / В. Б. Борисевич, Б. В. Борисевич. - К., 1997. - 143 с.

2. Гаскелл Р. Н. Справочник по инфекционным болезням собак и кошек / Р. Н. Гаскелл, М. Беннет. - М. : Аквариум, 2002. - 528 с.

3. Зелютков Ю. Г. Инфекционные болезни кошек / Ю. Г. Зелютков, В. А. Машеро, В. В. Петров. - Витебск : ВГАВМ, 2003. - 60 с.

4. Максимов Н. А. Инфекционные болезни собак и кошек / Н. А. Максимов, С. И. Лебедько. M. : 2000. $-128 \mathrm{c}$.

5. Руденко А. Ф. Инфекционные болезни кошек / А. Ф. Руденко и др. - Луганск : ЛНАУ, 2009. $-59 \mathrm{c}$.
6. Ремси Я. Инфекционные болезни собак и кошек / Я. Ремси, Б. Теннант // Практическое руководство. - М. : Аквариум, 2005. - 290 с.

7. Сулимов А. А. Вирусные болезни кошек/ А. А. Сулимов. - М. : Колос, 2004. - 86 с.

8. Щербина Е. В. Применение препаратов гамавит, фоспренил, максидин в схемах лечения заболеваний мелких домашних животных различной этиологии / Е. В. Щербина : матеріали 7-ї Міжнародної науково-практичної конференції «Проблеми ветеринарного обслуговування дрібних домашніх тварин». - К., 2002. - С. 83-85. 